\title{
Reinitialised versus continuous regional climate simulations using ALARO-0 coupled to the land surface model SURFEXv5
}

\author{
Julie Berckmans ${ }^{1,2}$, Olivier Giot ${ }^{1,2}$, Rozemien De $\operatorname{Troch}^{1,3}$, Rafiq Hamdi ${ }^{1,3}$, Reinhart Ceulemans ${ }^{2}$, and \\ Piet Termonia $^{1,3}$ \\ ${ }^{1}$ Royal Meteorological Institute, Brussels, Belgium \\ ${ }^{2}$ Centre of Excellence PLECO (Plant and Vegetation Ecology), Department of Biology, \\ University of Antwerp, Antwerp, Belgium \\ ${ }^{3}$ Department of Physics and Astronomy, Ghent University, Ghent, Belgium \\ Correspondence to: Julie Berckmans (julie.berckmans@meteo.be)
}

Received: 17 June 2016 - Published in Geosci. Model Dev. Discuss.: 9 August 2016

Revised: 22 December 2016 - Accepted: 23 December 2016 - Published: 16 January 2017

\begin{abstract}
Dynamical downscaling in a continuous approach using initial and boundary conditions from a reanalysis or a global climate model is a common method for simulating the regional climate. The simulation potential can be improved by applying an alternative approach of reinitialising the atmosphere, combined with either a daily reinitialised or a continuous land surface. We evaluated the dependence of the simulation potential on the running mode of the regional climate model ALARO coupled to the land surface model Météo-France SURFace EXternalisée (SURFEX), and driven by the ERA-Interim reanalysis. Three types of downscaling simulations were carried out for a 10-year period from 1991 to 2000, over a western European domain at $20 \mathrm{~km}$ horizontal resolution: (1) a continuous simulation of both the atmosphere and the land surface, (2) a simulation with daily reinitialisations for both the atmosphere and the land surface and (3) a simulation with daily reinitialisations of the atmosphere while the land surface is kept continuous. The results showed that the daily reinitialisation of the atmosphere improved the simulation of the $2 \mathrm{~m}$ temperature for all seasons. It revealed a neutral impact on the daily precipitation totals during winter, but the results were improved for the summer when the land surface was kept continuous. The behaviour of the three model configurations varied among different climatic regimes. Their seasonal cycle for the $2 \mathrm{~m}$ temperature and daily precipitation totals was very similar for a Mediterranean climate, but more variable for temperate and continental climate regimes. Commonly, the summer climate is characterised by strong interactions between
\end{abstract}

the atmosphere and the land surface. The results for summer demonstrated that the use of a daily reinitialised atmosphere improved the representation of the partitioning of the surface energy fluxes. Therefore, we recommend using the alternative approach of the daily reinitialisation of the atmosphere for the simulation of the regional climate.

\section{Introduction}

The first long-range simulation of the general circulation of the atmosphere dates back to 1956 (Phillips, 1956). Today it is still the primary tool for global climate projections. However, due to limited computer resources, the current horizontal resolution of $100-200 \mathrm{~km}$ is still too coarse to resolve sufficient detail for regional climate projections. Finer spatial resolution that resolves the land surface heterogeneity can be obtained by nesting a regional climate model (RCM), over a smaller domain, within a coarse-resolution global climate model (GCM). This is also referred to as dynamical downscaling. A GCM or global reanalysis data product provides the large-scale meteorological and surface fields to the RCM as initial and lateral boundary conditions. The global features are thus translated into regional and local conditions over the region of interest (Giorgi, 2006). Hence, RCMs enable climate simulations over a smaller domain with finer-scale horizontal resolution and with less expensive computational cost than running a GCM at the same resolution. 
Since the late 1960s, the numerical weather prediction (NWP) community has used high-resolution limited area models. The numerical approach was first used for a regional climate simulation by Dickinson et al. (1989). Their climate simulation used the NWP model in forecasting mode with 3-5 daily reinitialisations of the initial conditions. To be able to run them without these short-term reinitialisations, the regional climate community applied monthly to multidecadal simulations, with only a single initialisation of the large-scale fields and frequent updates of the lateral boundary conditions (Giorgi and Mearns, 1999). These long-term continuous simulations required improvements in the representation of physical processes in the RCMs. The continuous simulation is still the most common in the RCM community (Leung et al., 2003). However, by applying the continuous approach, the simulated large-scale fields deviate from the driving lateral boundary conditions (von Storch et al., 2000).

The accuracy of the dynamical downscaling has improved by using short-term reinitialisations to reduce systematic errors (Kotlarski et al., 2012; Qian et al., 2003; Lo et al., 2008; Lucas-Picher et al., 2013). However, only few in the RCM community adopted this method, mainly because of its higher computational costs. Most studies (Kotlarski et al., 2012; Qian et al., 2003; Lo et al., 2008) dealing with the evaluation of reinitialised versus continuous climate simulations, examined only short time periods of 1 month to 1 year. Using a daily reinitialisation, Kotlarski et al. (2012) showed improvements in the prediction of precipitation for a case study of a large flooding event in the Elbe river catchment in August 2002. Changing the period of reinitialisation, from monthly to 10 daily, a reduction in systematic errors has been shown for precipitation when using the 10-day reinitialisation (Qian et al., 2003). Even in a 20-year RCM simulation forced by reanalysis data, the sequence of events was better preserved by using daily reinitialisations (Lucas-Picher et al., 2013).

A model approach with short-term reinitialisations demands additional simulation time at each reinitialisation start. This time is required to reach dynamical equilibrium between the lateral boundary conditions and the internal model physics and dynamics (Giorgi and Mearns, 1999). Beyond $24 \mathrm{~h}$ small perturbations in the initial conditions of the atmosphere have only limited impact on the simulation potential (Anthes et al., 1989). In contrast to the atmosphere, the surface takes a longer time to reach dynamical equilibrium with the overlaying atmosphere, from a few weeks to several seasons, depending on the depth of the soil layer.

The surface interacts with the climate through the soil moisture and soil temperature, by influencing the surface energy budget (Giorgi and Mearns, 1999). The soil moisture controls the partitioning of the incoming energy into latent and sensible heat flux. The soil moisture limitation on the evapotranspiration is largest during summer (Seneviratne et al., 2010). The availability of soil moisture for evapotranspiration is determined by the $2 \mathrm{~m}$ temperature (Jaeger et al., 2009). As the land surface-atmosphere interactions play a crucial role in the representation of the current and future climate (Seneviratne et al., 2010), it is important to validate the model with observations. In-site measurements can provide valuable estimates of the surface energy fluxes. More specifically, FLUXNET establishes a global network of eddy-covariance towers measuring these fluxes (Baldocchi et al., 2001).

The objective of this study was to evaluate the simulation potential of three regional climate downscaling approaches with different update frequencies of the initial conditions: (1) a continuous simulation of both the atmosphere and the land surface, (2) a simulation with daily reinitialisations for both the atmosphere and the land surface and (3) a simulation with daily reinitialisations of the atmosphere while the land surface is kept continuous. We used the ALARO model to dynamically downscale the European Centre for Medium-Range Weather Forecasts (ECMWF) Interim ReAnalysis (ERA-Interim; Dee et al., 2011). Within this study, ALARO was coupled to the Météo-France SURFace EXternalisée land surface model (SURFEX; Masson et al., 2013). We evaluated the mean $2 \mathrm{~m}$ temperature and mean daily total precipitation by comparing with the $0.22^{\circ}$ ECA\&D E-OBS dataset (Haylock et al., 2008), and the surface energy fluxes by comparing with the FLUXNET database (Baldocchi et al., 2001). The analysis covered a 10-year period from 1991 to 2000, for a domain encompassing western Europe.

The models, experimental design and observational datasets are described in Sect. 2. The results for the mean surface parameters are covered in Sect. 3. Section 4 demonstrates the results with respect to the surface energy budget. Finally, conclusions are given in Sect. 5.

\section{Model and experimental design}

\subsection{Model definition}

The regional climate model used in this study is the ALARO model version 0 (ALARO-0), a configuration of the Aire Limitée Adaptation Dynamique Développement International (ALADIN) model with improved physical parameterisations (Gerard et al., 2009), combined with the Application de la Recherche à l'Opérationnel à Meso-Echelle (AROME), first baseline version released in 1998. The ALADIN model is the limited area model version of the global scale Action de Recherche Petite Echelle Grande Echelle Integrated Forecast system (ARPEGE-IFS) (Bubnová et al., 1995; ALADIN International Team, 1997). ARPEGE is a global spectral model, with a Gaussian grid for the grid-point calculation. The vertical discretisation uses hybrid terrain-following pressure coordinates. The ALARO-0 model has been developed with the ARPEGE Calcul Radiatif Avec Nebulosité (ACRANEB) scheme for radiation based on Ritter and Geleyn (1992). This ALARO-0 model configuration has been 


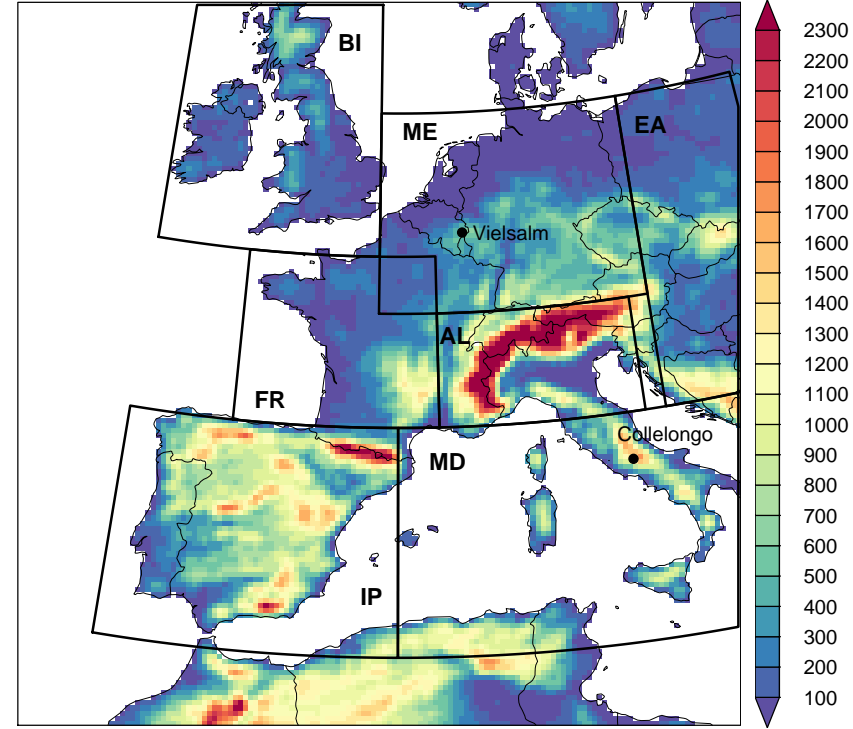

Figure 1. The total domain on $20 \mathrm{~km}$ horizontal resolution and the subdomains (BI, IP, FR, ME, AL, MD, EA) based on the subdomains selected in the EURO-CORDEX framework. The colour represents the orography $(\mathrm{m})$ in the ALARO + SURFEX set-up. The two FLUXNET stations focused on in this study are Vielsalm (maritime temperate climate) and Collelongo (humid subtropical climate).

operated at the Royal Meteorological Institute of Belgium for its operational numerical weather forecasts since 2010. The new physical parameterisation within the ALARO-0 model was specifically designed to run at convection-permitting scales, with a particular focus on an improved convection and cloud scheme (Gerard and Geleyn, 2005; Gerard, 2007; Gerard et al., 2009). The ALARO-0 model domain is centred over western Europe at $46.47^{\circ} \mathrm{N}$ and $2.58^{\circ} \mathrm{E}$ with a dimension of $149 \times 149$ horizontal grid points and spacing of $20 \mathrm{~km}$ in both horizontal axes, with a Lambert conformal projection (Fig. 1). The model consists of 46 vertical layers with the lowest model level at $17 \mathrm{~km}$ and the model top extending up to $72 \mathrm{~km}$.

The parameterisation of the land surface in ALARO-0 was initially made with the land surface scheme Interaction SoilBiosphere-Atmosphere (ISBA; Noilhan and Planton, 1989; Noilhan and Mahfouf, 1996). This scheme was designed for NWP and climate models, and describes the exchange of energy and water between the low-level atmosphere, vegetation and the soil surface, by using either a diffusion method (Boone and Wetzel, 1999), or a force restore method based on two or three layers (Noilhan and Planton, 1989). Using the initial set-up with ISBA, ALARO-0 has proven its skill for regional climate modelling with daily reinitialisations (Hamdi et al., 2012; De Troch et al., 2013). In addition, this set-up has been validated for continuous climate simulations and is now contributing to the EURO-CORDEX project (Giot et al., 2016; Jacob et al., 2014). Meanwhile the more recent land surface model SURFEX, with additional parameterisations for urban surface types, has been implemented in the ALARO-0 model (Hamdi et al., 2014). A NWP application with SURFEXv5 within ALARO-0 has shown neutral effects on the winter $2 \mathrm{~m}$ temperature and on the vertical profile of the wind speed. However, it has shown positive effects on the summer $2 \mathrm{~m}$ temperature, $2 \mathrm{~m}$ relative humidity, and resulted in improved precipitation scores compared to the previously used ISBA model (Hamdi et al., 2014). Whereas the validation of the implementation of SURFEXv5 within ALARO-0 has been done in a NWP context, this validation is also required in the context of long-term climate simulations. In this study, SURFEX uses the two-layer force restore method for ISBA. The first layer is the surface superficial layer, that directly interacts with the atmosphere, and the second layer is the combined bulk surface and rooting layer, which is determined at the depth were soil moisture flux becomes negligible for a period of ca. 1 week and is thus more important as a reservoir for soil moisture during dry periods (Noilhan and Planton, 1989).

SURFEX uses a tiling approach with each tile providing information on the surface fluxes according to the type of surface: nature, town, inland water and sea. The initial parameterisation ISBA for the nature tile was conserved, and the Town Energy Balance (TEB; Masson, 2000) was added as a parameterisation for the town tile. TEB uses a canopy approach with three urban energy budgets for the layers roof, wall and road. The ISBA and TEB schemes were combined, together with parameterisation schemes for inland water and seas, and externalised, based on the algorithm of Best et al. (2004). In other words, the code can be used inside a meteorological or climate model, or in stand alone mode. Each tile is divided in different patches, according to the tile type. These patches correspond to the plant functional types described in ECOCLIMAP (Masson et al., 2003). ECOCLIMAP is a $1 \mathrm{~km}$ horizontal resolution global land cover database and assigns the tile fraction and corresponding physical parameters (leaf area index: LAI, albedo, etc.) to SURFEX.

\subsection{Experimental design}

The regional climate model was driven by initial and lateral boundary conditions provided by the ERA-Interim reanalysis, available at a horizontal resolution of ca. $79 \mathrm{~km}$. A relaxation zone of eight grid points was used at the lateral boundaries of the domain (Davies, 1976). The zonal and meridional wind components, atmospheric temperature, specific humidity, surface pressure and soil moisture and soil temperature were updated every 6 model hours as lateral boundary conditions and interpolated to hourly distributions. They were introduced as initial conditions across the domain. A spin-up time was considered for the model to reach equilibrium between the lateral boundary conditions and the internal model physics (Giorgi and Mearns, 1999). Here we use 


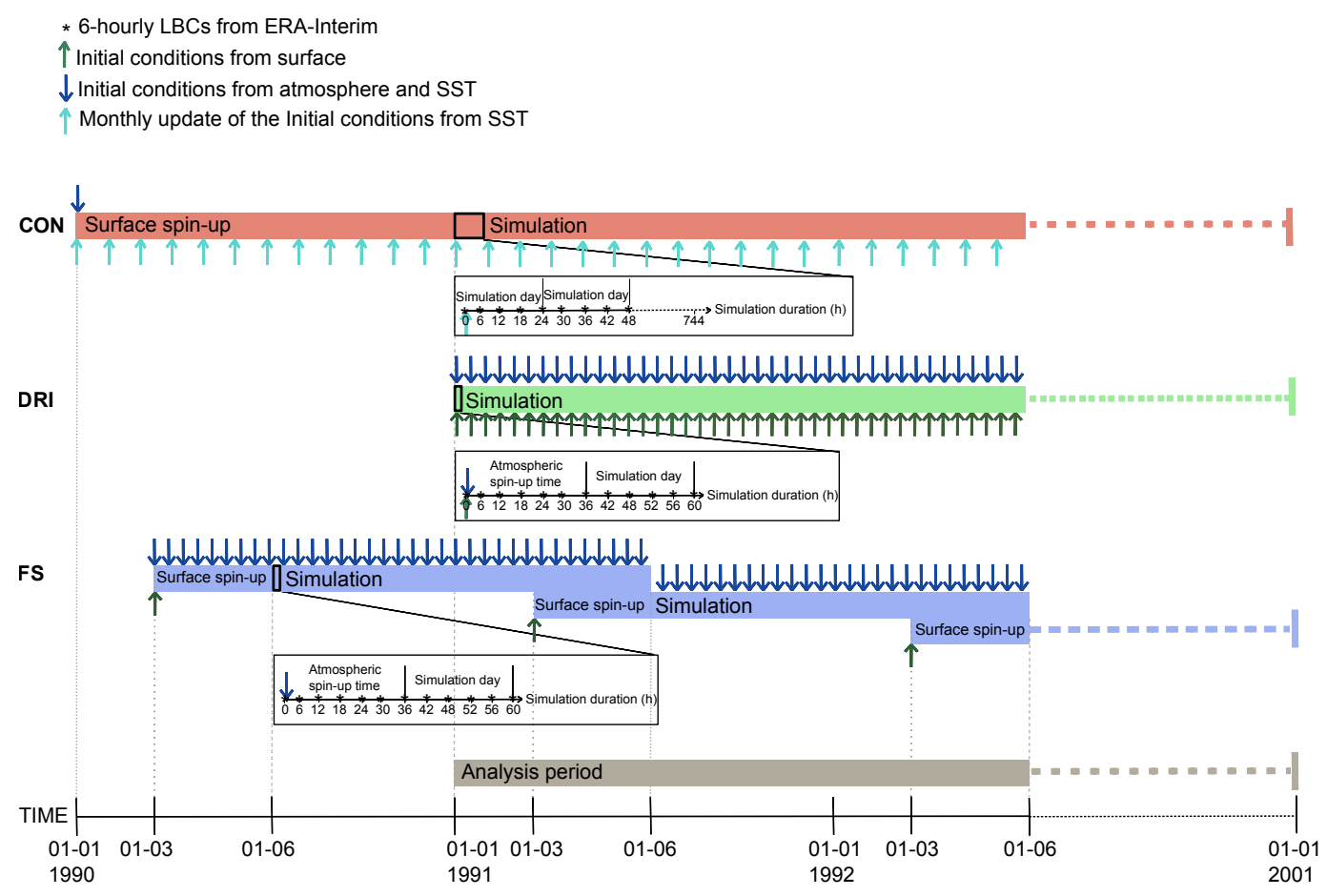

Figure 2. The set-up of the three downscaling approaches CON, DRI and FS used in this study. It represents the spin-up time for the different simulations, the analysis period of the total experiment and the update frequency of the lateral and initial boundary conditions.

an atmospheric spin-up, typically of a few days, and a land surface spin-up, typically of a few months to 1 year. The analysis covered a 10-year period from 00:00 UTC on 1 January 1991 to 00:00 UTC on 1 January 2001. Although the 10year length is arbitrary, it is sufficiently long to include some inter-annual variability and to generate a reasonable sample of extreme events. The use of a NWP model in a long-term climate setting for the performance of extreme precipitation events for a 10-year period was recently demonstrated (Lindstedt et al., 2015). To evaluate the sensitivity of the model to the update frequency of the initial conditions, three types of downscaling approaches were conducted with ALARO-0 coupled to SURFEXv5 and are detailed below.

The first downscaling approach was done by simulating the model in a continuous mode for both the atmosphere and the land surface (hereafter called CON ("CONtinuous"); Fig. 2). The model was started at 00:00 UTC on 1 January 1990, and ran continuously until 00:00 UTC on 1 January 2001. The first year was treated as both atmospheric and land surface spin-up, and was excluded from the analysis. The simulations were interrupted and restarted monthly to allow for only sea surface temperatures (SSTs) to be updated. Other surface parameters that were updated monthly using the climatological values from ECOCLIMAP were the vegetation fraction, surface roughness length, surface emissivity, surface albedo, sand and clay fractions.

In the second downscaling approach, the model was reinitialised daily for both the atmosphere and the land surface (hereafter called DRI (“Daily ReInitialisation"); Fig. 2). The model started at 12:00 UTC on 1 January 1991, and each reinitialisation ran for $60 \mathrm{~h}$. The first $36 \mathrm{~h}$ were treated as atmospheric spin-up, and excluded from the analysis. By applying this downscaling approach, the regional model stays close to the ERA-Interim forcing (von Storch et al., 2000). However, the coarse representation of the land surface by the reanalysis is not able to capture the fine-scale heterogeneity, particularly the soil moisture and soil temperature.

The third downscaling approach tries to find the best compromise between the previous two approaches. The atmosphere was reinitialised daily and the land surface was simulated continuously with a single initialisation (hereafter called FS ("Free Surface"); Fig. 2). This allowed the model to simulate the atmospheric fields close to the reanalysis forcing, together with a surface in equilibrium state. The model was run from 12:00 UTC on 1 March 1990 until 31 May 1991, and the atmosphere was reinitialised daily for a simulation time of $60 \mathrm{~h}$. The first $36 \mathrm{~h}$ were treated as atmospheric spin-up, and were excluded from the analysis. The land surface conditions were kept continuous by adding the land surface conditions for the $24 \mathrm{~h}$ period after the atmospheric spin-up to the land surface conditions of the previous daily simulation. In contrast to the atmospheric spin-up, the land surface spin-up lasted from 1 March until 31 May 1990, and this 3-month period was excluded from the analysis. Although CON required a 1-year spin-up, 3 months were sufficient for the FS deep soil moisture to reach equilibrium state, 
when starting in March (not shown). The simulations were done in parallel to each year from 1990 to 2000, and the 3 monthly spin-up was replaced by the analysis of the previous year.

We use 3-hourly output for the model evaluation presented in the manuscript. The evaluation of atmospheric variables for winter and summer was done for seven subdomains across Europe, to cover the spatial variability of the domain (Fig. 1). This was in agreement with the subdomains that were used in the EURO-CORDEX community (Kotlarski et al., 2014) and that were defined earlier in the framework of the "Prediction of Regional scenarios and Uncertainties for Defining European Climate change risks and Effects" (PRUDENCE) project (Christensen et al., 2007). The subdomains used in this study were the British Isles (BI), the Iberian Peninsula (IP), mid-Europe (ME), France (FR), the Alps (AL), the Mediterranean (MD) and eastern Europe (EA). The subdomains IP, ME and EA were chosen due to their diverse climate regimes to evaluate the yearly cycle of the atmospheric and land surface variables. As land surface processes play an important role primarily during summer, the model output was stored at every hour for the summer period of June-July-August (JJA) during the 10-year period. We evaluated the partitioning of the sensible and latent heat fluxes by the daily maximum Bowen ratio (BR; Bowen, 1926) for the summer periods from 1996 to 2000 for the total study domain, and compared a subset of FLUXNET stations using the corresponding model grid points. The corresponding daily maximum BRs were analysed for the 10-year summer period from 1991 to 2000 . When the $\mathrm{BR}<1$, the latent heat flux (LE) is greater than the sensible heat flux $(\mathrm{H})$. Conversely when $\mathrm{BR}>1, \mathrm{LE}$ is less than $\mathrm{H}$. The diurnal cycles of all surface energy fluxes were also analysed and validated against observations.

\subsection{Observational reference data}

The results of the climate simulations were validated against E-OBS, a daily high-resolution gridded observational dataset (Haylock et al., 2008). The dataset consists of the daily mean temperature, the daily maximum and minimum temperature, and the daily precipitation total. The most recent version v12.0 was selected on the $0.22^{\circ}$ rotated pole grid, corresponding to a $25 \mathrm{~km}$ horizontal resolution in Europe. It covers the period 1 January 1950 to 30 June 2015 . In order to validate the model data, the ALARO-0 data at $20 \mathrm{~km}$ horizontal resolution were bilinearly interpolated towards E-OBS at $25 \mathrm{~km}$ horizontal resolution and replotted to our study domain. A careful interpretation of E-OBS is necessary, as this regridded non-homogeneously distributed network applies a smoothing out of extreme precipitation and consequently a large underestimation of the mean precipitation (Haylock et al., 2008).

For the validation of the surface fluxes in the model, we used measurements from the FLUXNET level 3 flux tower database (Baldocchi et al., 2001). It provides information on the energy exchange between the ecosystem and the atmosphere. FLUXNET is a global network, and consists of flux towers using the eddy-covariance method to monitor carbon dioxide and water vapour exchange rates, and energy flux densities. No gap-filling has been done and the comparison to the model output was only done at hours when observational data were available. A number of sites were already part of a separate flux measurement network (Aubinet et al., 1999). The model validation was done using grid cell averages compared to point observations, suggesting large differences in the land cover representation. In total, a subset of seven stations, which cover different biome types (Table 1), were selected to demonstrate the spatial variability of the domain by the model. However, the main focus was on the Vielsalm and Collelongo sites (Fig. 1), as their model grid cells represent more than $50 \%$ of the corresponding land cover, and cover different climate regimes.

\section{Validation of the mean model state}

\subsection{Spatial distribution}

\subsubsection{Daily mean $2 \mathrm{~m}$ temperature}

The spatial distributions of the 10-year daily mean temperature bias (absolute, (model - observed)) of CON, DRI and FS simulations were compared to E-OBS (Fig. 3), for winter (DJF: December-January-February) and summer (JJA). The area-averaged bias during winter and summer for $\mathrm{CON}$, DRI and FS for the entire domain as well as for specific subdomains is presented in Table 2. CON simulated a cold bias in general, except for northern Africa in summer, with a pronounced orographic effect, for both winter and summer (Fig. 3c, d). The cold bias over the entire domain was less pronounced in summer with a value of $-0.6^{\circ} \mathrm{C}$ compared to the winter bias of $-1.8^{\circ} \mathrm{C}$ (Table 2). Moreover, the Iberian Peninsula, Mediterranean and eastern Europe resulted in a small bias of $-0.5^{\circ} \mathrm{C}$ during summer as compared to E-OBS (Fig. 3d). This is due to compensating effects, as the bias represents an average over the subdomain and might be the result of large negative and large positive biases over different parts of the particular subdomain compensating each other. However, the area-averaged bias gives a good impression of the ranking of the experiments (Kotlarski et al., 2014).

With respect to CON, DRI demonstrated a reduction of the cold bias during winter and summer, particularly for the eastern part of the domain (Fig. 3e, f). The area-averaged bias for eastern Europe was close to zero for DRI during winter and summer (Table 2), in spite of many significant non-zero bias points for the summer (Fig. 3e, f). A large improvement of the $2 \mathrm{~m}$ temperature simulation by DRI was also produced for mid-Europe and the Alps with a winter bias of -0.7 and $-1.4^{\circ} \mathrm{C}$ respectively, which is about half 
Table 1. Overview of the FLUXNET eddy-covariance sites used in this study.

\begin{tabular}{llrrrlll}
\hline Site and reference & Short & Long. $\left({ }^{\circ} \mathrm{E}\right)$ & Lat. $\left({ }^{\circ} \mathrm{N}\right)$ & Alt. $(\mathrm{m})$ & Biome type & Years & Climate zone $(\mathrm{Köppen})$ \\
\hline Vielsalm & BEVie & 6.00 & 50.31 & 491 & Mixed & $1996-2000$ & Maritime temperate $(\mathrm{Cfb})$ \\
Collelongo & ITCol & 13.59 & 41.85 & 1645 & Deciduous & $1996-2000$ & Humid subtropical $(\mathrm{Cfa})$ \\
Brasschaat & BEBra & 4.52 & 51.31 & 15 & Deciduous & $1997-2000$ & Maritime temperate $(\mathrm{Cfb})$ \\
Loobos & NLLoo & 5.74 & 52.17 & 25 & Evergreen & $1996-2000$ & Maritime temperate $(\mathrm{Cfb})$ \\
Tharandt & DETha & 13.57 & 50.96 & 320 & Evergreen & $1996-2000$ & Maritime temperate $(\mathrm{Cfb})$ \\
Hesse & FRHes & 7.07 & 48.67 & 293 & Deciduous & $1997-2000$ & Maritime temperate $(\mathrm{Cfb})$ \\
Le Bray & FRLBr & -0.77 & 44.72 & 62 & Evergreen & $1996-2000$ & Maritime temperate $(\mathrm{Cfb})$ \\
\hline
\end{tabular}

Table 2. The daily mean $2 \mathrm{~m}$ temperature bias $\left({ }^{\circ} \mathrm{C}\right.$ ) and root mean square error (RMSE) (in brackets) between the downscaled simulations and E-OBS for the total domain and the subdomains (BI, IP, FR, ME, AL, MD, EA) during DJF and JJA for the 10-year period from 1991 to 2000 .

\begin{tabular}{rlrrrrrrrr}
\hline & & Total & BI & IP & FR & ME & AL & MD & EA \\
\hline DJF & CON & $-1.8(2.5)$ & $-1.1(2.0)$ & $-2.2(2.7)$ & $-1.5(2.2)$ & $-1.3(2.0)$ & $-3.0(3.8)$ & $-2.4(3.1)$ & $-1.1(2.0)$ \\
& DRI & $-1.2(2.8)$ & $-1.0(2.7)$ & $-1.6(2.7)$ & $-1.2(2.9)$ & $-0.7(2.6)$ & $-1.4(3.4)$ & $-2.1(3.2)$ & $-0.3(2.8)$ \\
& FS & $-1.0(2.8)$ & $-0.3(2.8)$ & $-1.3(2.5)$ & $-0.7(2.8)$ & $-0.4(2.6)$ & $-2.1(3.8)$ & $-1.2(2.7)$ & $-0.4(2.8)$ \\
\hline \multirow{2}{*}{ JJA } & CON & $-0.6(2.0)$ & $-1.7(2.0)$ & $-0.5(1.7)$ & $-1.2(1.9)$ & $-1.3(1.9)$ & $-1.8(2.6)$ & $-0.5(2.0)$ & $-0.5(1.8)$ \\
& DRI & $-0.1(2.3)$ & $-0.9(2.0)$ & $-0.3(2.2)$ & $-0.7(2.4)$ & $-0.3(2.1)$ & $-0.8(2.3)$ & $-0.6(2.3)$ & $0.0(2.1)$ \\
& FS & $0.9(2.7)$ & $-0.7(2.2)$ & $0.5(2.4)$ & $1.0(3.1)$ & $1.3(2.8)$ & $0.0(2.5)$ & $0.7(2.5)$ & $1.2(2.8)$ \\
\hline
\end{tabular}

of the bias of CON. For summer, the bias decreases further to $-0.3^{\circ} \mathrm{C}(\mathrm{ME})$ and $-0.8^{\circ} \mathrm{C}(\mathrm{AL})$; a $1{ }^{\circ} \mathrm{C}$ decrease relative to $\mathrm{CON}$ for these subdomains. The frequent reinitialisations keep the large scales closer to the ERA-Interim forcing, whereas ALARO and ARPEGE are bound to a cold bias (Voldoire et al., 2013; Giot et al., 2016).

The performance of the FS simulation was different for winter and summer (Fig. $3 \mathrm{~g}, \mathrm{~h}$ ). The simulation of the $2 \mathrm{~m}$ temperature during winter was the best of all three approaches when using FS. Large parts of the domain resulted in biases close to zero for the British Isles, France, midEurope and eastern Europe (Fig. 3g). The bias decreased by ca. $1^{\circ} \mathrm{C}$ in $\mathrm{FS}$ compared to $\mathrm{CON}$ for these subdomains (Table 2). During summer, the sign of the bias reversed from negative to positive, except for some isolated areas (Fig. 3h). The Alps were characterised by a zero bias on the northern flank and mixed cold and warm bias on the southern flank compensating each other (Table 2). Large parts of the Iberian Peninsula and the Mediterranean exhibited a warm bias (Fig. 3h), resulting in positive values close to zero (Table 2). Mid-Europe, France and eastern Europe were mainly characterised by a positive bias of around $1{ }^{\circ} \mathrm{C}$ (Table 2). These positive biases for FS might be related to rapidly decreasing soil moisture values in spring and summer (not shown). The temperature-soil moisture relation is strongest for FS, as this simulation benefits from soil moisture memory by allowing the land surface to be fully interactive with the atmosphere (Koster and Suarez, 2001).

In summary, CON underestimated winter and summer $2 \mathrm{~m}$ temperature by $1-2{ }^{\circ} \mathrm{C}$ on average. With respect to $\mathrm{CON}$,
DRI showed a general positive effect during winter and summer. Consequently, the use of a daily reinitialised atmosphere improved the representation of the $2 \mathrm{~m}$ temperature for both winter and summer compared to a continuous simulation of the atmosphere. The winter bias was further improved for most subdomains for FS compared to CON. For summer, most subdomains experienced a warm bias, in the same order of magnitude as CON. The difference might point at the interaction of the land surface and the atmosphere being stronger with FS, because of the soil moisture memory.

\subsubsection{Daily accumulated precipitation}

The spatial distributions of the 10-year daily accumulated precipitation bias (relative, (model-observed) / observed) of CON, DRI and FS were compared to E-OBS, for the winter and the summer seasons (Fig. 4). The relative biases during winter and summer for CON, DRI and FS are presented for the entire domain as well as for the specific subdomains in Table 3. The precipitation pattern of E-OBS during winter displayed the highest values of $>3 \mathrm{~mm}_{\text {day }}{ }^{-1}$ over Portugal, north-western Spain, western England, Scotland and Ireland, the Adriatic Coast and the northern flanks of the Alps (Fig. 4a, b). During summer, similar amounts of rainfall were concentrated over the Alps and the Carpathians, whereas the lowest values of $<1 \mathrm{~mm} \mathrm{day}^{-1}$ were concentrated over the Iberian Peninsula, the Mediterranean and northern Africa.

During winter, all simulations demonstrated a similar spatial variability of the wet bias, except for a dry bias in northern Africa (Fig. 4c, e, g). In general, ALARO was forced 

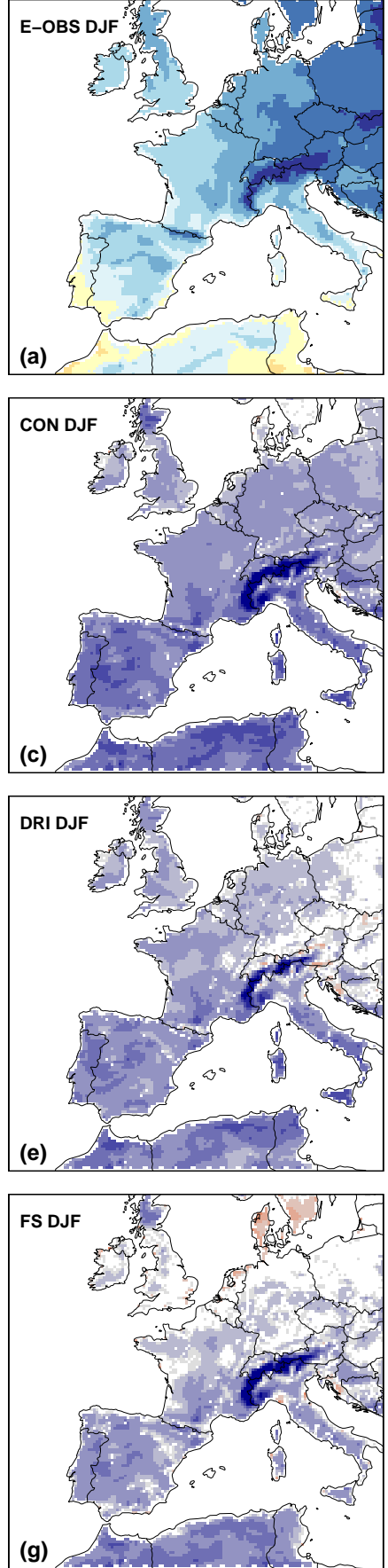
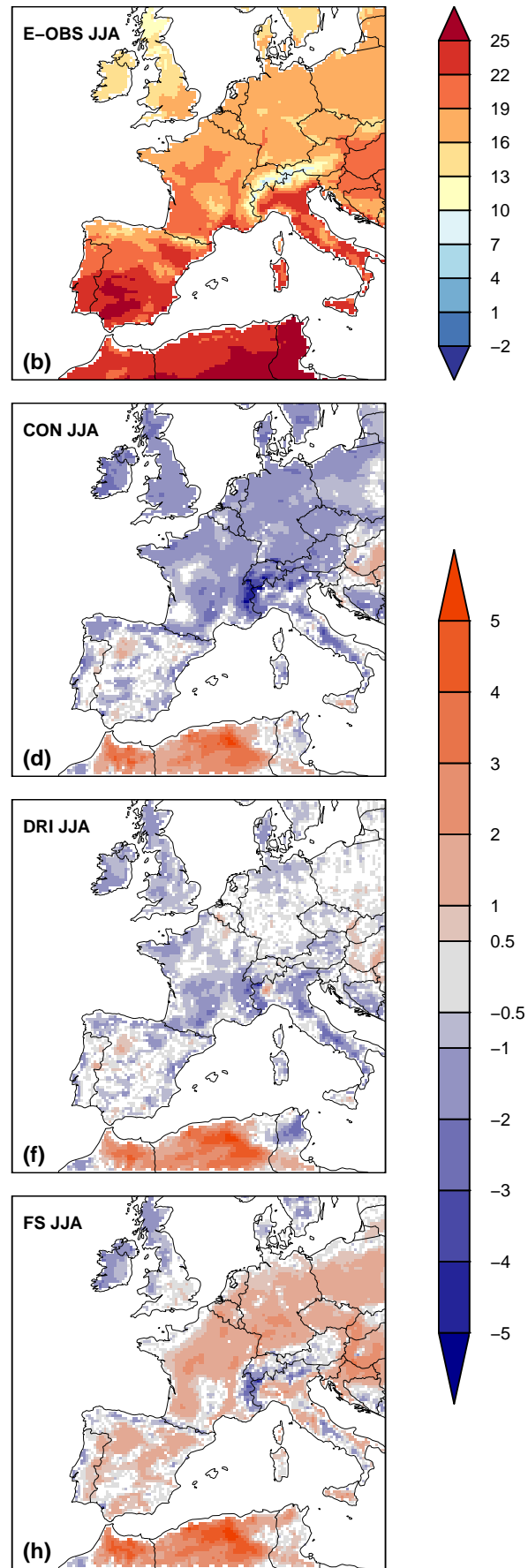

Figure 3. Daily mean $2 \mathrm{~m}$ temperature $\left({ }^{\circ} \mathrm{C}\right)$ for E-OBS DJF (a) and JJA (b), and absolute bias $\left({ }^{\circ} \mathrm{C}\right)$ of the model with E-OBS for CON DJF (c) and JJA (d), for DRI DJF (e) and JJA (f) and for FS DJF (g) and JJA (h), all at a $20 \mathrm{~km}$ horizontal resolution for the 10-year period from 1991 to 2000. Only the significant biases are shown, using the Student's $t$ test at a $5 \%$ level, and non-significant biases are shown in white.

towards the too wet driving fields of ERA-Interim (LucasPicher et al., 2013), which can explain part of the overestimated precipitation. More specifically, the overestimation of winter precipitation was strongest in the Mediterranean and eastern Europe with values from 35.3 to $108.5 \%$ for all simulation modes (Table 3). The large values in the Mediterranean agreed with the large underestimation of $2 \mathrm{~m}$ temperature, as this region is characterised by a strong dependence of temperature and precipitation (Faggian, 2015). The area-averaged bias for the entire domain was larger for FS 
Table 3. The daily accumulated precipitation bias (\%) and root mean square error (RMSE) (in brackets) between the downscaled simulations and E-OBS for the total domain and the subdomains (BI, IP, FR, ME, AL, MD, EA) during DJF and JJA for the 10-year period from 1991 to 2000 .

\begin{tabular}{rlrrrrrrrr}
\hline & & Total & BI & IP & FR & ME & AL & MD & EA \\
\hline \multirow{2}{*}{ DJF } & CON & $16.6(3.8)$ & $4.5(4.5)$ & $16.1(4.6)$ & $29.0(3.6)$ & $25.4(2.7)$ & $11.2(4.7)$ & $46.0(6.2)$ & $35.3(2.3)$ \\
& DRI & $20.9(4.8)$ & $6.6(5.2)$ & $21.2(5.6)$ & $26.8(4.8)$ & $27.9(3.8)$ & $24.1(6.3)$ & $41.6(7.1)$ & $45.7(3.1)$ \\
& FS & $36.3(5.4)$ & $16.9(5.5)$ & $31.3(6.2)$ & $38.2(5.2)$ & $35.7(4.0)$ & $26.7(6.7)$ & $108.5(9.9)$ & $64.1(3.5)$ \\
\hline \multirow{2}{*}{ JJA } & CON & $12.1(4.2)$ & $24.7(4.4)$ & $11.5(2.9)$ & $12.0(4.4)$ & $11.9(5.0)$ & $32.6(7.3)$ & $60.7(3.5)$ & $-2.6(5.4)$ \\
& DRI & $22.5(4.7)$ & $27.0(4.7)$ & $30.0(3.4)$ & $18.3(5.1)$ & $8.8(5.5)$ & $48.2(8.9)$ & $84.8(3.8)$ & $6.8(5.9)$ \\
& FS & $3.6(4.5)$ & $17.4(4.6)$ & $13.0(3.2)$ & $-7.0(4.6)$ & $-13.4(5.1)$ & $23.5(8.3)$ & $52.4(3.6)$ & $-8.2(5.7)$ \\
\hline
\end{tabular}

in winter with ca. $36.3 \%$ compared to 16.6 and $20.9 \%$ for CON and DRI. The too wet driving field of ERA-Interim was superimposed on the smaller cold bias of FS, suggesting a higher precipitation bias than CON and DRI.

During summer, the simulations showed different spatial variability (Fig. 4d, f, h). In comparison to the winter bias, the summer precipitation bias for CON was reduced over the continental part with positive and negative biases over the southern part of the domain (Fig. 4d). The Mediterranean expressed a high wet bias of $60.7 \%$ for CON, but the absolute values in summer were close to zero, as it is characterised by a climate with dry summers (Fig. 4b). The bias pattern over the continental part was very similar for DRI compared to CON during summer, whereas southern Europe showed increased wet biases for DRI (Fig. 4f). The Iberian Peninsula, France and the Mediterranean demonstrated a bias of 30.0, 18.3 and $84.8 \%$ respectively, compared to $11.5,12.0$ and $60.7 \%$ with CON (Table 3 ). The performance of FS was similar to CON for southern and eastern Europe (Fig. 4h). This is in contrast to the continental part of the domain, where the precipitation signal reversed relative to CON and DRI and a small dry bias persisted $(-7.0 \%$ for France, $-13.4 \%$ for mid-Europe and $-8.2 \%$ for eastern Europe respectively). Consequently, the summer precipitation was simulated better by FS than by CON and DRI. During summer, the influence of the soil moisture memory on the atmosphere is more important, resulting in an improved representation of the precipitation with FS.

In summary, the model was characterised by a wet bias in winter and summer. The spatial variability during winter was very similar for all simulations; therefore, the use of a daily reinitialised atmosphere had a neutral impact on the winter precipitation. During summer, the precipitation showed a different behaviour with the different simulation modes. In summer for the southern part of the domain, precipitation bias experienced a neutral effect with DRI, whereas the precipitation bias increased for the continental part. Frequent reinitialisations did not allow the land surface to build up a soil moisture memory, resulting in less skill for the representation of the precipitation. However, the precipitation bias improved with FS for the continental part. Therefore, the combination of the daily reinitialised atmosphere together with a continuous surface is crucial in summer to get the best results.

\subsection{Mean annual cycle}

\subsubsection{Daily mean $2 \mathrm{~m}$ temperature}

To validate specific subdomains within the larger domain on a monthly scale, the mean annual cycles of the downscaled simulations were compared to the observations (Fig. 5). We focused on the following subdomains (Fig. 1): (1) the Iberian Peninsula at the western boundary of the domain with its warm and dry summer climate, (2) mid-Europe with its temperate climate and (3) eastern Europe at the eastern boundary of the domain with its continental climate.

The daily mean $2 \mathrm{~m}$ temperature reached $23^{\circ} \mathrm{C}$ for the Iberian Peninsula, and $20^{\circ} \mathrm{C}$ for both mid-Europe and eastern Europe (Fig. 5a-c). For these selected subdomains, all downscaled simulations presented very similar autumn (SON: September-October-November) temperatures, but underestimated them with respect to E-OBS. Therefore, the autumn temperature is not sensitive to the updated frequency of the initial conditions. Regarding the other seasons, the simulations revealed a different behaviour in the representation of the $2 \mathrm{~m}$ temperature with respect to the observations.

For the Iberian Peninsula, the $2 \mathrm{~m}$ temperature was generally underestimated for all seasons (Fig. 5a). Except for autumn, FS was closer to the observations as compared to CON and DRI, resulting in a yearly mean temperature of $12.5^{\circ} \mathrm{C}$, which was closer to the observed yearly mean temperature of $13.7^{\circ} \mathrm{C}$ as compared to 11.6 and $11.9^{\circ} \mathrm{C}$ by CON and DRI respectively. Therefore, summer $2 \mathrm{~m}$ temperature was well simulated by FS for this subdomain. For mid-Europe, CON and DRI underestimated the $2 \mathrm{~m}$ temperature for all seasons, and FS was very close to the observations from February to May (Fig. 5b). However, FS overestimated the summer $2 \mathrm{~m}$ temperature and $\mathrm{CON}$ and DRI underestimated the summer $2 \mathrm{~m}$ temperature. Still, the yearly mean value of $9.0^{\circ} \mathrm{C}$ by FS was very close to the observational mean of $9.3^{\circ} \mathrm{C}$. For eastern Europe, DRI and FS demonstrated almost identical behaviour for the simulation of the $2 \mathrm{~m}$ temperature during winter and spring (MAM: March-April-May) with small bi- 

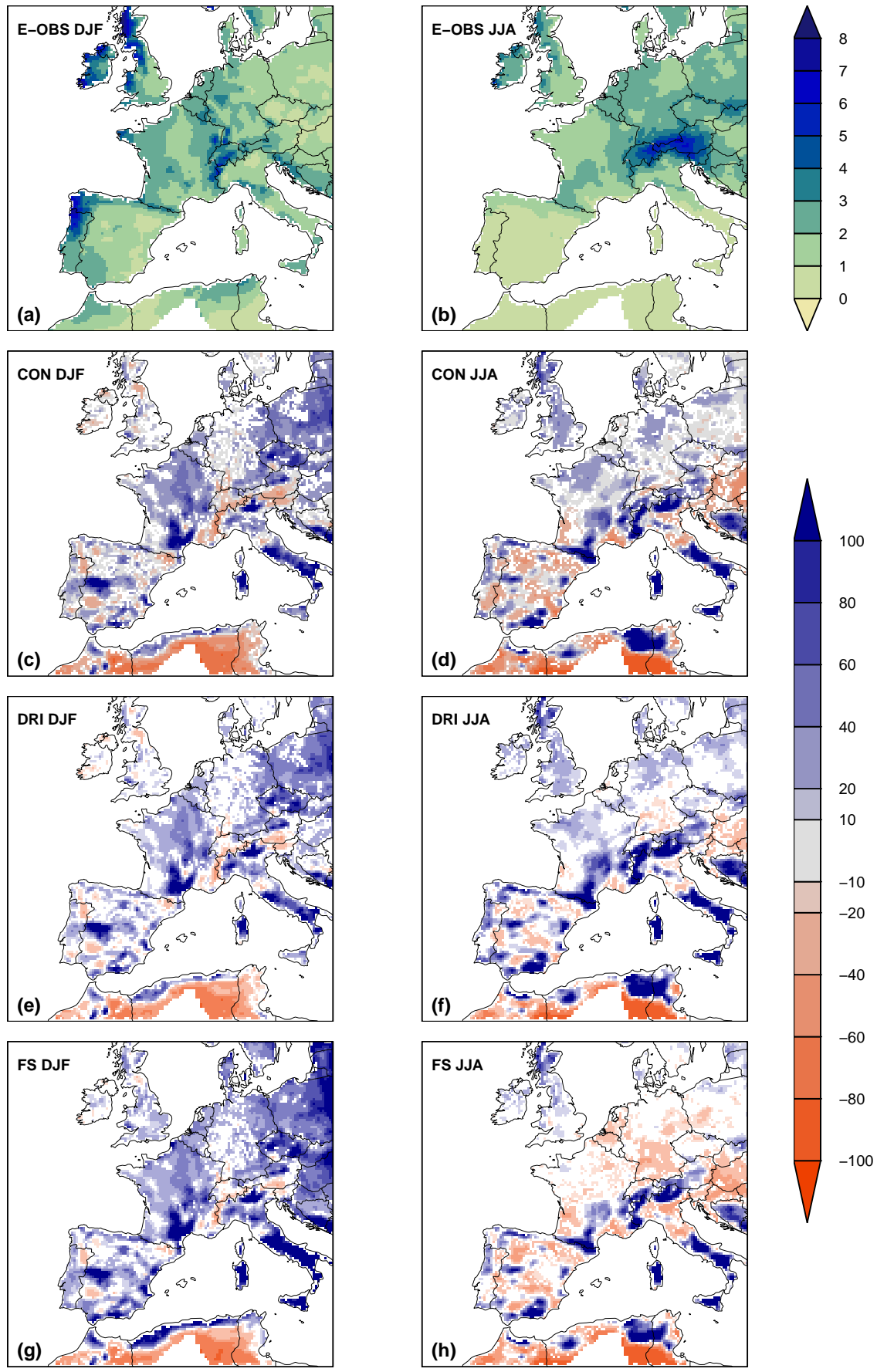

Figure 4. Daily accumulated precipitation $\left(\mathrm{mm} \mathrm{day}^{-1}\right)$ for E-OBS DJF (a) and JJA (b), and relative bias (\%) of the model with E-OBS for CON DJF (c) and JJA (d), for DRI DJF (e) and JJA (f) and for FS DJF (g) and JJA (h), all at a $20 \mathrm{~km}$ horizontal resolution for a 10-year period from 1991 to 2000. Only the significant biases are shown, using the $F$ test at a $5 \%$ level, and non-significant biases are shown in white.

ases (Fig. 5c), whereas CON underestimated the $2 \mathrm{~m}$ temperature. Similar to mid-Europe, FS overestimated the summer $2 \mathrm{~m}$ temperature with ca. $1{ }^{\circ} \mathrm{C}$ and $\mathrm{CON}$ underestimated the summer $2 \mathrm{~m}$ temperature with ca. $1^{\circ} \mathrm{C}$ in eastern Europe. Yet again, the yearly mean value of $8.5^{\circ} \mathrm{C}$ by FS was very sim- ilar as compared to the observations with a value of $8.6^{\circ} \mathrm{C}$, while largest differences occurred using $\mathrm{CON}$ with a value of $7.5^{\circ} \mathrm{C}$.

In summary, the yearly mean temperature was underestimated by CON for all subdomains. In general, ALARO is 

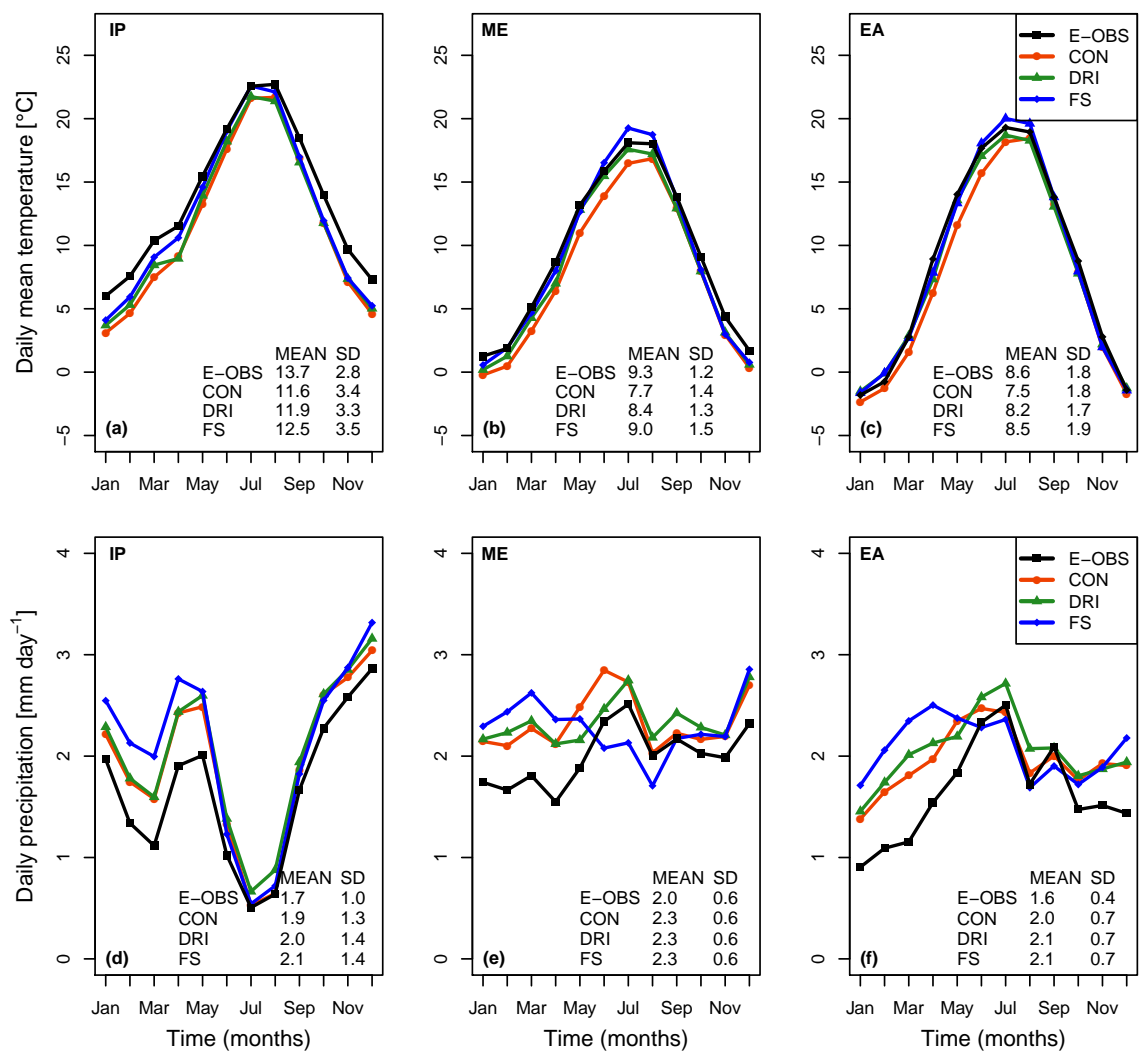

Figure 5. Mean annual cycle of the daily $2 \mathrm{~m}$ temperature $\left({ }^{\circ} \mathrm{C}\right)$ with E-OBS, CON, DRI and FS for (a) the Iberian Peninsula, (b) mid-Europe, and (c) eastern Europe and daily accumulated precipitation $\left(\mathrm{mm} \mathrm{day}^{-1}\right)$ for (d) the Iberian Peninsula, (e) mid-Europe and (f) eastern Europe, averaged over the 10-year period from 1991 to 2000. Both the mean and standard deviation (SD) are displayed as text.

bound to a cold bias (Giot et al., 2016). Along the selected subdomains, there were larger differences between the simulations in mid-Europe and eastern Europe compared to the Iberian Peninsula. The dry climate of the Iberian Peninsula is less dominated by land surface-atmosphere interactions, as soil moisture does not impact the evapotranspiration availability (Seneviratne et al., 2010). DRI was able to simulate the $2 \mathrm{~m}$ temperature better for mid-Europe and eastern Europe as compared to $\mathrm{CON}$ for winter, spring and summer. FS had the best yearly mean $2 \mathrm{~m}$ temperature, but the summer $2 \mathrm{~m}$ temperature was overestimated by FS for mid-Europe and eastern Europe.

\subsubsection{Daily accumulated precipitation}

Similar to temperature, the monthly means of the daily accumulated precipitation, averaged over the 10-year period, are shown in Fig. 5 for the Iberian Peninsula, mid-Europe and eastern Europe. When comparing the observations, the seasonal variability was most pronounced for the Iberian Peninsula, with minimum precipitation values of ca. $0.5 \mathrm{~mm} \mathrm{day}^{-1}$ during summer, and maximum precipitation values of ca. $3 \mathrm{~mm}$ day $^{-1}$ during spring, autumn and beginning of the winter (Fig. 5d). The precipitation in mid-Europe reached high- est values of ca. $3 \mathrm{~mm} \mathrm{day}^{-1}$ during summer (Fig. 5e). The continental climate of eastern Europe presented average values of $1 \mathrm{~mm} \mathrm{day}^{-1}$ for winter and spring, while most rainfall occurred in the summer of ca. $2.5 \mathrm{~mm} \mathrm{day}^{-1}$ (Fig. 5f).

In general, the agreement of the simulations was the largest during autumn. For the Iberian Peninsula, the seasonal pattern of the downscaled simulations followed the seasonal pattern of E-OBS, despite a general overestimation of the precipitation (Fig. 5d). This overestimation was stronger in winter and in spring for the Iberian Peninsula, and is in agreement with Lucas-Picher et al. (2013). For these two seasons, E-OBS showed an undercatch of the precipitation, which might have amplified the model biases (Rauscher et al., 2010). CON and DRI were closer to the observations than FS in winter and spring, resulting in yearly mean values of 1.9, 2.0 and $2.1 \mathrm{~mm} \mathrm{day}^{-1}$ respectively for CON, DRI and FS, as compared to the observational mean value of $1.7 \mathrm{~mm} \mathrm{day}^{-1}$. In mid-Europe, the model overestimated the precipitation for most of the year, except for summer (Fig. 5e). During summer, FS showed a large underestimation, whereas CON and DRI showed similar overestimates of precipitation. The precipitation in eastern Europe (Fig. 5f) was overestimated by the model during most of the year, except for summer (Lucas-Picher et al., 2013), where there 


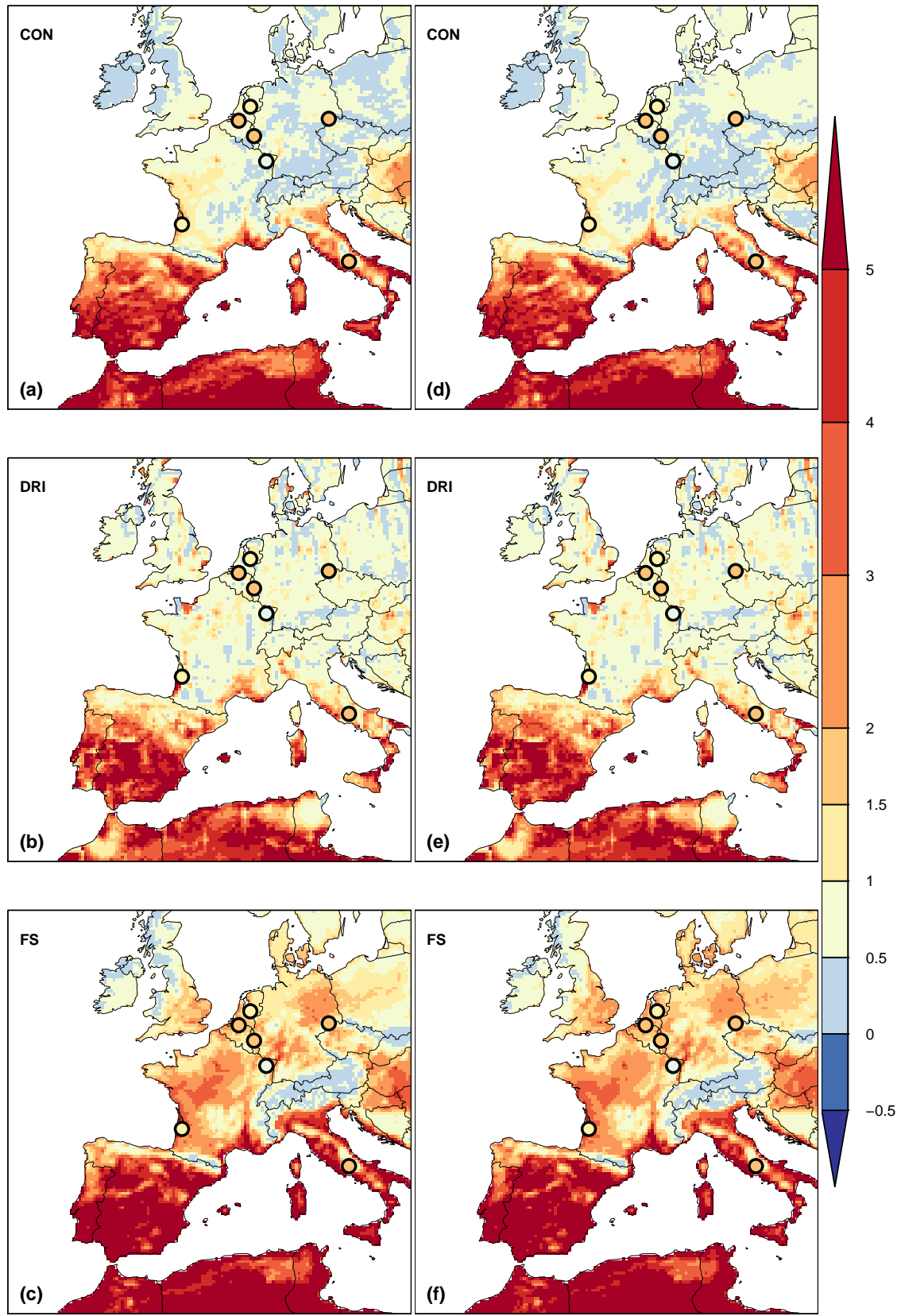

Figure 6. Daily maximum Bowen ratio averaged over the 5-year JJA period from 1996 to 2000 for (a) CON, (b) DRI and (c) FS and averaged over the 10-year JJA period 1991-2000 for (d) CON, (e) DRI and (f) FS. The dots represent the values for the FLUXNET stations Vielsalm, Collelongo, Brasschaat, Loobos, Tharandt, Hesse and Le Bray.

is considerable agreement on the estimation of the summer precipitation. The yearly mean precipitation by $\mathrm{CON}$ was lowest with $2.0 \mathrm{~mm} \mathrm{day}^{-1}$ and highest when using FS with $2.1 \mathrm{~mm} \mathrm{day}^{-1}$, as compared to $1.6 \mathrm{~mm} \mathrm{day}^{-1}$ by the observations (Fig. 5f).

In summary, the three downscaling approaches generally overestimated the precipitation over these three regions in all seasons except during JJA. On a yearly basis, the differences between CON, DRI and FS were small; on the other hand, on a monthly basis the magnitude of differences were regionally dependent with larger differences between the model simulations for mid-Europe and eastern Europe compared to the Iberian Peninsula. 

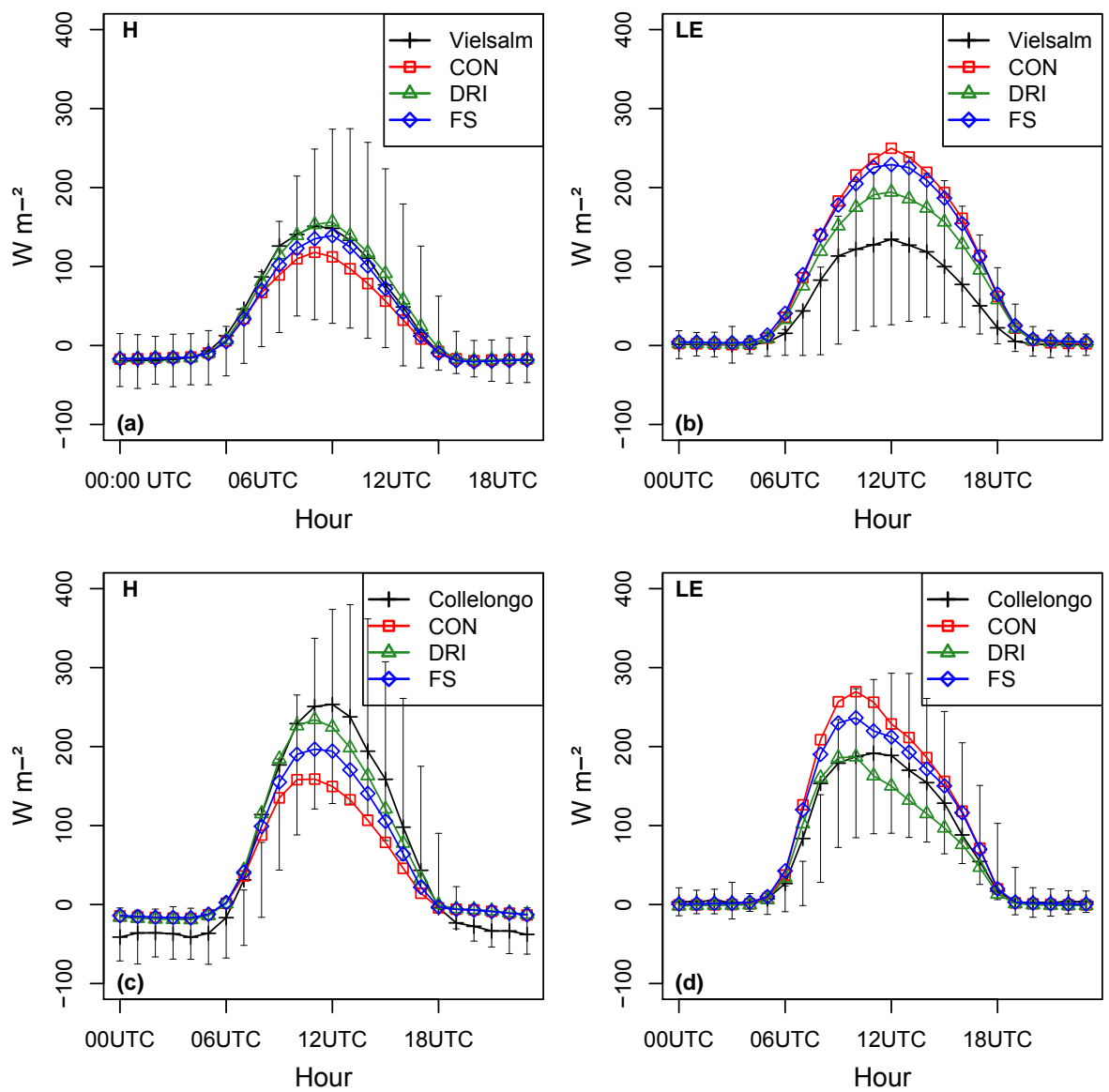

Figure 7. Daily cycle of the energy fluxes $\left(\mathrm{W} \mathrm{m}^{-2}\right.$ ) in JJA 1996-2000 for Vielsalm in the top row and Collelongo in bottom row for (a, c) H, and $(\mathbf{b}, \mathbf{d})$ LE, for the FLUXNET observations and their corresponding model grid points by CON, DRI and FS. The error bars represent the estimated uncertainties of the observed turbulent fluxes.

\section{Validation of surface fluxes}

The spatial distributions of the 5-year daily maximum BR, at the time of maximum $\mathrm{H}$ and LE, of CON, DRI and FS were compared to FLUXNET observations, for the summer period only (Fig. 6a-c). The corresponding spatial distributions of the 10-year daily maximum BR of CON, DRI and FS were evaluated with respect to the results for the 5-year period (Fig. 6d-f). The mean diurnal cycles of the surface energy fluxes are illustrated over the 5-year summer period from 1996 to 2000 for the FLUXNET stations of Vielsalm and Collelongo and their corresponding model grid points (Fig. 7, Table 4).

The daily maximum BR showed a strong gradient of increasing values towards the south of the domain (Fig. 6a-c). Recall that when the value is lower (higher) than 1, the latent heat flux (LE) is higher (lower) than the sensible heat flux $(\mathrm{H})$. Southern Europe is characterised by dry summers, with a strong control of the soil moisture on the evapotranspiration (Jaeger et al., 2009), and thus lower LE than H. Large differences existed between the three downscaling ap- proaches, particularly for the continental part of the domain. This is in agreement with the larger differences between the simulation modes in $2 \mathrm{~m}$ temperature for the continental subdomains compared to the southern subdomains. Therefore, the $2 \mathrm{~m}$ temperature is correlated to evapotranspiration by the sensitivity of LE on the soil moisture (Seneviratne et al., 2006).

CON had relatively low BR values of 0 to 1 for the continental area, DRI showed BR values of 0.5 to 1 and FS had the highest values of 2 to 3 . The larger values presented by FS were in agreement with the warm and dry summer bias. Comparison with the FLUXNET observations showed a general underestimation of BR for CON and DRI, whereas FS estimated well the BR for most of the sites. The FLUXNET sites show typically a closure imbalance of $20 \%$ (Wilson et al., 2002), whereas it was assumed that the BR is well estimated by the eddy-covariance system (Napoly et al., 2016). Though this validation was based on five summer periods only from 1996 to 2000, it was still robust as indicated by the corresponding BR for the 10-year summer period from 1991 to 2000 (Fig. 6d-f, Table 4). Considering the two FLUXNET 
Table 4. The daily maximum surface energy fluxes $\left(\mathrm{W} \mathrm{m}^{-2}\right)$ averaged over the 5-year JJA period from 1996 to 2000 and the 10 -year period from 1991 to 2000 (in brackets).

\begin{tabular}{llrrrrr}
\hline & & RN & H & LE & G & BR \\
\hline Vielsalm & OBS & 417 & 151 & 134 & 11 & 1.12 \\
& CON & $395(404)$ & $118(113)$ & $250(261)$ & $47(47)$ & $0.47(0.43)$ \\
& DRI & $388(398)$ & $151(159)$ & $195(193)$ & $57(58)$ & $0.78(0.82)$ \\
& FS & $405(411)$ & $139(152)$ & $229(221)$ & $46(49)$ & $0.61(0.69)$ \\
\hline Collelongo & OBS & 538 & 253 & 192 & -1.39 & 1.32 \\
& CON & $480(481)$ & $159(147)$ & $270(289)$ & $111(108)$ & $0.59(0.51)$ \\
& DRI & $496(494)$ & $247(232)$ & $183(194)$ & $143(140)$ & $1.35(1.19)$ \\
& FS & $501(498)$ & $197(191)$ & $236(247)$ & $111(110)$ & $0.83(0.77)$ \\
\hline
\end{tabular}

sites Vielsalm and Collelongo, DRI indicates the best agreement with the observed BR (Fig. 6b), with values of 0.78 and 1.35 compared to 1.12 and 1.32 respectively (Table 4). Despite higher BR values in FS, estimates corresponding to Vielsalm and Collelongo were located in regions where the BR was comparatively low, resulting in average values of 0.61 and 0.83 respectively (Table 4 ).

The model performed well for the simulation of the daily cycle of the net radiation (RN; not shown), even though the model underestimated the values of RN by ca. $5-10 \%$ (Table 4). The model generally underestimated $\mathrm{H}$, and overestimated LE (Fig. 7 and Table 4). The ground heat flux (G) showed improbably high values compared to the observed ones (Table 4). G is dependent on the soil temperature, which was largely overestimated by the land surface model (not shown). The standard version of ISBA, the nature tile of SURFEX, aggregates soil and vegetation properties for each grid cell (Noilhan and Planton, 1989). The net radiation is directly transferred to the ground, causing an inaccurate partitioning of the incoming energy into turbulent and ground heat fluxes (Napoly et al., 2016). An additional parameterisation for the leaf litter on the surface soil impacts this distribution (Wilson et al., 2012). We suggest to include an explicit formulation of the canopy layer (Napoly et al., 2016) and potentially a parameterisation for the forest litter layer (Napoly et al., 2016; Wilson et al., 2012). The implementation of these explicit formulations in ISBA outperformed the representation of the soil temperature of the original ISBA model (Napoly et al., 2016). They showed that the original ISBA model overestimated the G flux amplitude with several tens of $\mathrm{W} \mathrm{m}^{-2}$ during both daytime and nighttime. However, using the distinct surface energy budgets resolved part of the overestimated $\mathrm{G}$ by intercepting most of the downward solar radiation, leaving more energy available for turbulent fluxes. Consequently, less net radiation reaches the forest surface, reducing the energy available for the soil conductance Napoly et al. (2016).

For Vielsalm, H was simulated well by DRI and FS during nighttime and daytime, whereas CON underestimated $\mathrm{H}$ during daytime (Fig. 7a). The daily maximum $\mathrm{H}$ by $\mathrm{CON}$ was only $118 \mathrm{~W} \mathrm{~m}^{-2}$, as compared to 151 and $139 \mathrm{~W} \mathrm{~m}^{-2}$ for DRI and FS respectively (Table 4). This validation was only done for five summer periods from 1996 to 2000, but the corresponding daily maximum values for the 10 -year summer period from 1991 to 2000 indicate that the 5-year period was representative for the validation of the fluxes (Table 4). The LE was overestimated by all simulations, but the difference in the observations was smallest for DRI, due to the frequent land surface reinitialisations, compared to the highest values for CON. The daily maximum BR was lower than 1 for all downscaling approaches (Table 4). This means that they all simulated a higher latent than sensible heat flux. Still, DRI and FS showed higher values for BR than CON. Therefore, the partitioning of the surface energy fluxes was better represented by DRI and FS for the station of Vielsalm.

For Collelongo, the model underestimated $\mathrm{H}$ during daytime and overestimated $\mathrm{H}$ during nighttime, except for DRI, which demonstrated a good agreement with the observations. Consequently, the model overestimated LE during daytime, except for DRI. The daily maximum $\mathrm{H}$ for DRI of $247 \mathrm{~W} \mathrm{~m}^{-2}$ was close to the observed value of $253 \mathrm{~W} \mathrm{~m}^{-2}$, whereas CON and FS simulated much lower values of 159 and $197 \mathrm{~W} \mathrm{~m}^{-2}$ respectively (Table 4). CON showed the largest LE bias. Regarding BR, the simulation by DRI with a value of 1.35 was in very good agreement with the observations. The DRI simulation resulted in the least biased partitioning of the surface energy fluxes at Collelongo. However, FS showed that frequent atmospheric reinitialisations can add value.

In summary, the model presented a good spatial variability of BR, and the agreement with observations was highest for FS. However, when focusing on the sites that represent at least $50 \%$ of the land cover at the corresponding model grid cell, it was DRI that performed well for $\mathrm{H}$ at Vielsalm and for LE at Collelongo. For Collelongo, this resulted in the least biased simulation of the partitioning of the surface energy fluxes, translating into a better BR estimate. The use of a daily reinitialised atmosphere and land surface improved the correct partitioning of the surface energy fluxes, whereas the continuous land surface initialisation as in FS 
could not improve the representation of the surface energy fluxes. The high values of $\mathrm{G}$ were caused by the large overestimation of the soil temperature and could be solved by implementing additional parameterisations for the canopy layer and soil surface layer. This implementation could alter the energy budget available for the turbulent fluxes, but this lies outside the scope of this study.

\section{Conclusions}

An assessment of three downscaling approaches has been performed using the regional climate model ALARO-0 coupled to the land surface model SURFEXv5, with lateral and initial boundary conditions from ERA-Interim. The simulations were applied for a 10-year period from 1991 to 2000, for a western European domain. The performance of ALARO-0 with SURFEX has already been validated for NWP applications (Hamdi et al., 2014), and here we present an evaluation for long-term climate simulations.

We compared the commonly used approach of a continuous climate simulation with two alternative methods of frequently reinitialising the RCM boundary conditions, combined with either a daily reinitialised or continuous land surface. The use of a daily reinitialised atmosphere outperformed the continuous (CON) approach for winter and summer $2 \mathrm{~m}$ temperature, and deteriorated the summer precipitation. However, the use of a continuous land surface (FS) with a daily reinitialised atmosphere improved the summer precipitation relative to the full continuous approach. Furthermore, it improved the winter $2 \mathrm{~m}$ temperature, whereas it resulted in a neutral impact on the summer $2 \mathrm{~m}$ temperature and the winter precipitation, despite a slight deterioration over the Mediterranean. The SSTs were reinitialised daily together with the atmosphere, as compared to the monthly updated SSTs in the continuous approach.

The seasonal cycle of the $2 \mathrm{~m}$ temperature and precipitation was different for three selected subdomains that covered large climate variability. Both the temperate climate of mid-Europe and the continental climate of eastern Europe indicated more seasonal variability than the Mediterranean climate of the Iberian Peninsula. The simulation of the $2 \mathrm{~m}$ temperature had improved when applying daily reinitialised atmosphere with continuous land surface, despite an overestimation of the summer $2 \mathrm{~m}$ temperature. Precipitation biases were larger and are perhaps associated with the tendency for ERA-Interim to be wetter than E-OBS, and the low spatial coverage by the observations in some regions. It was clear that the agreement for the precipitation between the model and the observations was highest during summer, while other seasons showed stronger deviations.

During summer, the interaction between the land surface and the overlaying atmosphere is largest. The $2 \mathrm{~m}$ temperature interacts with the soil moisture and influences the partitioning of the surface energy fluxes. The daily reinitialisa- tion of the atmosphere improved the correct partitioning of the latent and sensible heat flux, although the biases were still quite large to be conclusive. Still, this approach outperformed the use of a continuous simulation. For a more comprehensive analysis, future research will consider including more FLUXNET stations. A more in-depth analysis on the interaction between $2 \mathrm{~m}$ temperature, precipitation and surface energy fluxes can reveal soil-moisture-temperature coupling (Jaeger et al., 2009), but this lies outside the scope of this study.

In conclusion, this study demonstrated that the approach of a daily reinitialised atmosphere was superior over the full continuous approach. The use of a continuous surface next to a daily reinitialised atmosphere improved the winter temperature and summer precipitation. We recommend using FS in a set-up with GCM forcing for climate simulations with ALARO-0.

\section{Code and data availability}

The used ALADIN codes, along with all related intellectual property rights, are owned by the members of the ALADIN consortium. Access to the ALADIN System, or elements thereof, can be granted upon request and for research purposes only. The used SURFEX codes are freely available, together with the ECOCLIMAP database, at http: //www.cnrm-game-meteo.fr/surfex///spip.php?rubrique8.

This study is based on large datasets written in .FA and .lfi format. The relevant output is exported to R datasets. Due to licensing restrictions, this model output is not made publicly available. However, for the purpose of the review, the data can be made available for the editor and reviewer upon request by contacting Julie Berckmans.

Author contributions. J. Berckmans performed the model simulations CON, DRI, and FS and analysed the results. J. Berckmans drafted the manuscript. O. Giot and R. De Troch designed R tools for the analysis. O. Giot designed the experiment CON. R. Hamdi designed the experiment DRI and FS and developed the model code for the implementation of SURFEX within ALARO-0. P. Termonia and R. Ceulemans provided overall guidance during the project. R. Ceulemans and R. Hamdi were the project contractors. All co-authors contributed to the writing and the revising of the manuscript.

Acknowledgement. We acknowledge the E-OBS dataset from the EU-FP6 project ENSEMBLES (http://ensembles-eu. metoffice.com) and the data providers in the ECA\&D project (http://www.ecad.eu). This work used eddy-covariance data acquired and shared by the FLUXNET community. The validation data have been collected and prepared by the individual site PIs and their teams. We would like to thank Marc Aubinet (Vielsalm), Giorgio Matteucci (Collelongo), Reinhart Ceulemans, Ivan Janssens (Brasschaat), Eddy Moors (Loobos), Christian Bernhofer 
(Tharandt), Bernard Longdoz (Hesse) and Denis Loustau (Le Bray) for contributing data to this study. This research was funded by the Belgian Federal Science Policy Office under the BRAIN.be program as MASC contract no. BR/121/A2 and supported by the research project no. BR/132/A1/FORBIOCLIMATE. The authors thank A. L. Hirsch and the anonymous referee for their valuable suggestions to improve the manuscript notably. The authors also like to thank Annelies Duerinckx (Royal Meteorological Institute of Belgium, Brussels) for the fruitful discussions.

Edited by: D. Lawrence

Reviewed by: A. L. Hirsch and one anonymous referee

\section{References}

ALADIN International Team: The ALADIN project: Mesoscale modelling seen as a basic tool for weather forecasting and atmospheric research, WMO Bulletin, 46, 317-324, 1997.

Anthes, R. A., Kuo, Y.-H., Hsie, E.-Y., Low-Nam, S., and Bettge, T. W.: Estimation skill and uncertainty in regional numerical models, Q. J. Roy. Meteor. Soc., 115, 763-806, 1989.

Aubinet, M., Grelle, A., Ibrom, A., Rannik, U., Moncrieff, J., Foken, T., Kowalski, A. S., Martin, P. H., Berbigier, P., Bernhofer, Ch., Clement, R., Elbers, J., Granier, A., Grünwald, T., Morgenstern, K., Pilegaard, K., Rebmann, C., Snijders, W., Valentini, R., and Vesala, T.: Estimates of the annual net carbon and water exchange of forests: the EUROFLUX methodology, Adv. Ecol. Res., 30, 113-175, 1999.

Baldocchi, D., Falge, E., Lianhong, G., Olson, R., Hollinger, D., Running, S., Anthoni, P., Bernhofer, Ch., Davis, K., Evans, R., Fuentes, J., Goldstein, A., Katul, G., Law, B., Lee, X., Malhi, Y., Meyers, T., Munger, W., Oechel, W., Paw, K. T., Pilegaard, K., Schmid, H. P., Valentini, R., Verma, S., Vesala, T., Wilson, K., and Wofsy, S.: FLUXNET: a new tool to study the temporal and spatial variability of ecosystem-scale carbon dioxide, water vapor and energy flux densities, B. Am. Meteorol. Soc., 82, 24152435, 2001.

Best, M. J., Beljaars, A., Polcher, J., and Viterbo, P.: A proposed structure for coupling tiled surfaces with the planetary boundary layer, J. Hydrometeorol., 5, 1271-1278, 2004.

Boone, A. and Wetzel, P. J.: A simple method for modeling sub-grid soil texture variability for use in an atmospheric climate model, J. Meteorol. Soc. Jpn., 77, 317-333, 1999.

Bowen, I. S.: The ratio of heat losses by conduction and by evaporation from any water surface, Phys. Rev. Lett., 27, 779-787, 1926.

Bubnová, R., Hello, G., Bénard, P., and Geleyn, J.-F.: Integration of the fully elastic equations cast in the hydrostatic pressure terrainfollowing coordinate in the framework of the ARPEGE/Aladin NWP system, Mon. Weather Rev., 123, 515-535, 1995.

Christensen, J. H., Carter, T. R., Rummukainen, M., and Amanatidis, G.: Evaluating the performance and utility of regional climate models: the PRUDENCE project, Climate Change, 81, 1-6, 2007.

Davies, H. C.: A lateral boundary formulation for multi-level prediction models, Q. J. Roy. Meteor. Soc., 102, 405-418, 1976.

De Troch, R., Hamdi, R., Van De Vyver, H., Geleyn, J.-F., and Termonia, P.: Multiscale performance of the ALARO-0 Model for simulating extreme summer precipitation climatology in Belgium, J. Climate, 26, 8895-8915, 2013.

Dee, D. P., Uppala, S. M., Simmons, A. J., Berrisford, P., Poli, P., Kobayashi, S., Andrae, U., Balmaseda, M. A., Balsamo, G., Bauer, P., Bechtold, P., Beljaars, A. C. M., van de Berg, L., Bidlot, J., Bormann, N., Delsol, C., Dragani, R., Fuentes, M., Geer, A. J., Haimberger, L., Healy, S. B., Hersbach, H., Hólm, E. V., Isaksen, L., Kållberg, P., Köhler, M., Matricardi, M., McNally, A. P., Monge-Sanz, B. M., Morcrette, J.-J., Park, B.-K., Peubey, C., de Rosnay, P., Tavolato, C., Thépaut, J.-N., and Vitart, F.: The ERA-Interim reanalysis: configuration and performance of the data assimilation system, Q. J. Roy. Meteor. Soc., 137, 553-597, 2011.

Dickinson, R. E., Errico, R. M., Giorgi, F., and Bates, G. T.: A regional climate model for the Western United States, Clim. Change, 15, 383-422, 1989.

Faggian, P.: Climate Change Projections for Mediterranean Region with Focus over Alpine Region and Italy, J. Environ. Sci. Eng., 4, 482-500, 2015.

Gerard, L.: An integrated package for subgrid convection, clouds and precipitation compatible with the meso-gamma scales, Q. J. Roy. Meteor. Soc., 133, 711-730, 2007.

Gerard, L. and Geleyn, J.-F.: Evolution of a subgrid deep convection parametrization in a limited area model with increasing resolution, Q. J. Roy. Meteor. Soc., 131, 2293-2312, 2005.

Gerard, L., Piriou, J.-M., Brozková, R., Geleyn, J.-F., and Banciu, D.: Cloud and precipitation parameterization in a meso-gammascale operational weather prediction model, Mon. Weather Rev., 137, 3960-3977, 2009.

Giorgi, F.: Regional climate modeling: status and perspectives, J. Physics, 139, 101-118, 2006.

Giorgi, F. and Mearns, L. O.: Introduction to special section: regional climate modeling revisited, J. Geophys. Res., 104, 63356352, 1999.

Giot, O., Termonia, P., Degrauwe, D., De Troch, R., Caluwaerts, S., Smet, G., Berckmans, J., Deckmyn, A., De Cruz, L., De Meutter, P., Duerinckx, A., Gerard, L., Hamdi, R., Van den Bergh, J., Van Ginderachter, M., and Van Schaeybroeck, B.: Validation of the ALARO-0 model within the EURO-CORDEX framework, Geosci. Model Dev., 9, 1143-1152, doi:10.5194/gmd-9-11432016, 2016.

Hamdi, R., Van de Vyver, H., and Termonia, P.: New cloud and microphysics parameterisation for use in high-resolution dynamical downscaling: application for summer extreme temperature over Belgium, Int. J. Climatol., 32, 2051-2065, 2012.

Hamdi, R., Degrauwe, D., Duerinckx, A., Cedilnik, J., Costa, V., Dalkilic, T., Essaouini, K., Jerczynki, M., Kocaman, F., Kullmann, L., Mahfouf, J.-F., Meier, F., Sassi, M., Schneider, S., Vána, F., and Termonia, P.: Evaluating the performance of SURFEXv5 as a new land surface scheme for the ALADINcy36 and ALARO-0 models, Geosci. Model Dev., 7, 23-39, doi:10.5194/gmd-7-23-2014, 2014.

Haylock, M. R., Hofstra, N., Klein Tank, A. M. G., Klok, E. J., Jones, P. D., and New, M.: A European daily highresolution gridded data set of surface temperature and precipitation for 1950-2006, J. Geophys. Res., 113, D20119, doi:10.1029/2008JD010201, 2008.

Jacob, D., Petersen, J., Eggert, B., Alias, A., Christensen, O. B., Bouwer, L. M., Braun, A., Colette, A., Déqué, M., Georgievski, 
G., Georgopoulou, E., Gobiet, A., Menut, L., Nikulin, G., Haensler, A., Hempelmann, N., Jones, C., Keuler, K., Kovats, S., Kröner, N., Kotlarski, S., Kriegsmann, A., Martin, E., van Meijgaard, E., Moseley, C., Pfeifer, S., Preuschmann, S., Radermacher, C., Radtke, K., Rechid, D., Rounsevell, M., Samuelsson, P., Somot, S., Soussana, J.-F., Teichmann, C., Valentini, R., Vautard, R., Weber, B., and Yiou, P.: EURO-CORDEX: new highresolution climate change projections for European impact research, Reg. Environ. Change, 14, 563-578, 2014.

Jaeger, E. B., Stöckli, R., and Seneviratne, S. I.: Analysis of planetary boundary layer fluxes and land-atmosphere coupling in the regional climate model CLM, J. Geophys. Res., 114, 1-15, 2009.

Koster, R. D. and Suarez, M. J.: Soil moisture memory in climate models, J. Hydrometeorology, 2, 558-570, 2001.

Kotlarski, S., Hagemann, S., Krahe, P., Podzun, R., and Jacob, D.: The Elbe river flooding 2002 as seen by an extended regional climate model, J. Hydrology, 472-473, 169-183, 2012.

Kotlarski, S., Keuler, K., Christensen, O. B., Colette, A., Déqué, M., Gobiet, A., Goergen, K., Jacob, D., Lüthi, D., van Meijgaard, E., Nikulin, G., Schär, C., Teichmann, C., Vautard, R., Warrach-Sagi, K., and Wulfmeyer, V.: Regional climate modeling on European scales: a joint standard evaluation of the EUROCORDEX RCM ensemble, Geosci. Model Dev., 7, 1297-1333, doi:10.5194/gmd-7-1297-2014, 2014.

Leung, L. R., Mearns, L. O., Giorgi, F., and Wilby, R. L.: Regional climate research, B. Am. Meteorol. Soc., 84, 89-95, 2003.

Lindstedt, D., Lind, P., Kjellström, E., and Jones, C.: A new regional climate model operating at the meso-gamma scale: performance over Europe, Tellus, 67, 1-23, 2015.

Lo, J. C.-F., Yang, Z.-L., and Pielke Sr., R. A.: Assessment of three dynamical climate downscaling methods using the Weather Research and Forecasting (WRF) model, J. Geophys. Res., 113, 116, 2008.

Lucas-Picher, P., Boberg, F., Christensen, J. H., and Berg, P.: Dynamical downscaling with reinitializations: a method to generate finescale climate datasets suitable for impact studies, J. Hydrometeorol., 14, 1159-1174, 2013.

Masson, V.: A physically-based scheme for the urban energy budget in atmospheric models, Bound.-Lay. Meteorol., 94, 357-397, 2000.

Masson, V., Champeaux, J.-L., Chauvin, F., Meriguet, C., and Lacaze, R.: A global database of land surface parameters at $1 \mathrm{~km}$ resolution in meteorological and climate models, J. Climate, 16, 1261-1282, 2003.

Masson, V., Le Moigne, P., Martin, E., Faroux, S., Alias, A., Alkama, R., Belamari, S., Barbu, A., Boone, A., Bouyssel, F., Brousseau, P., Brun, E., Calvet, J.-C., Carrer, D., Decharme, B., Delire, C., Donier, S., Essaouini, K., Gibelin, A.-L., Giordani, H., Habets, F., Jidane, M., Kerdraon, G., Kourzeneva, E., Lafaysse, M., Lafont, S., Lebeaupin Brossier, C., Lemonsu, A., Mahfouf, J.-F., Marguinaud, P., Mokhtari, M., Morin, S., Pigeon, G., Salgado, R., Seity, Y., Taillefer, F., Tanguy, G., Tulet, P., Vincendon, B., Vionnet, V., and Voldoire, A.: The SURFEXv7.2 land and ocean surface platform for coupled or offline simulation of earth surface variables and fluxes, Geosci. Model Dev., 6, 929-960, doi:10.5194/gmd-6-929-2013, 2013.
Napoly, A., Boone, A., Samuelsson, P., Gollvik, S., Martin, E., Seferian, R., Carrer, D., Decharme, B., and Jarlan, L.: The Interactions between Soil-Biosphere-Atmosphere (ISBA) land surface model Multi-Energy Balance (MEB) option in SURFEX - Part 2: Model evaluation for local scale forest sites, Geosci. Model Dev. Discuss., doi:10.5194/gmd-2016-270, in review, 2016.

Noilhan, J. and Mahfouf, J.-F.: The ISBA land surface parameterisation scheme, Global Planet. Change, 13, 145-159, 1996.

Noilhan, J. and Planton, S.: A simple parameterization of land surface processes for meteorological models, Mon. Weather Rev., 117, 536-549, 1989.

Phillips, N. A.: The general circulation of the atmosphere: a numerical experiment, Q. J. Roy. Meteor. Soc., 82, 123-164, 1956.

Qian, J.-H., Seth, A., and Zebiak, S.: Reinitialized versus continuous simulations for regional climate downscaling, Mon. Weather Rev., 131, 2857-2874, 2003.

Rauscher, S. A., Coppola, E., Piani, C., and Giorgi, F.: Resolution effects on regional climate model simulations of seasonal precipitation over Europe, Clim. Dynam., 35, 685-711, 2010.

Ritter, B. and Geleyn, J.-F.: A comprehensive radiation scheme for numerical weather prediction models with potential applications in climate simulations, Mon. Weather Rev., 120, 303-325, 1992.

Seneviratne, S. I., Lüthi, D., Litschi, M., and Schär, C.: Landatmosphere coupling and climate change in Europe, Nature, 443, 205-209, 2006.

Seneviratne, S. I., Corti, T., Davin, E. L., Hirschi, M., Jaeger, E. B., Lehner, I., Orlowsky, B., and Teuling, A. J.: Investigating soil moisture-climate interactions in a changing climate: A review, Earth-Sci. Rev., 99, 125-161, 2010.

Voldoire, A., Sanchez-Gomez, E., Salas y Mélia, D., Decharme, B., Cassou, C., Sénési, S., Valcke, S., Beau, I., Alias, A., Chevalier, M., Déqué, M., Deshayes, J., Douville, H., Fernandez, E., Madec, G., Maisonnave, E., Moine, M.-P., Planton, S., SaintMartin, D., Szopa, S., Tyteca, S., Alkama, R., Belamari, S., Braun, A., Coquart, L., and Chauvin, F.: The CNRM-CM5.1 global climate model: description and basic evaluation, Clim. Dynam., 40, 2091-2121, 2013.

von Storch, H., Langenberg, H., and Feser, F.: A spectral nudging technique for dynamical downscaling purposes, Mon. Weather Rev., 128, 3664-3673, 2000.

Wilson, K., Goldstein, A., Falge, E., Aubinet, M., Baldocchi, D., Berbigier, P., Bernhofer, C., Ceulemans, R., Dolman, H., Field, C., Grelle, A., Ibrom, A., Law, B. E., Kowalski, A., Meyers, T., Moncrieff, J., Monson, R., Oechel, W., Tenhunen, J., Valentini, R., and Verma, S.: Energy balance closure at FLUXNET sites, Agr. Forest Meteorol., 113, 223-243, 2002.

Wilson, T. B., Meyers, T. P., Kochendorfer, J., Anderson, M. C., and Heuer, M.: The effect of soil surface litter residue on energy and carbon fluxes in a deciduous forest, Agr. Forest Meteorol., 161, 134-147, 2012. 